\title{
Row orientation effects on chemical composition and aromatic profile of Syrah winter wines
}

\author{
Renata Vieira da MOTA ${ }^{1 \star}$ (D), Isabela PEREGRINO ${ }^{1}$, Camila Pinheiro Carvalho SILVA ${ }^{1}$, \\ Ricardo Henrique Paulino RAIMUNDO ${ }^{1}$, Fernanda de Paula FERNANDES ${ }^{1}$, Claudia Rita de SOUZA ${ }^{1}$
}

\begin{abstract}
Sunlight and heating influence leaf and grape metabolism and therefore wine quality. As a recent management tool, no information exists on the effects of grapevine row orientation on the wine composition of Syrah vines within the context of double pruning management, a technique used to transfer the grape harvest from the wet summer to the dry winter season. This is a first attempt to investigate the wine composition from north-south- (NS) and east-west- (EW) oriented Syrah winter vines. EW wine samples had higher total acidity, residual sugars, alcohol and color hue, whereas NS wines exhibited higher content of color intensity, anthocyanins, total phenolics, total phenolic index, ashes and $\mathrm{pH}$. The identification of volatile compounds was tentatively performed and demonstrated the presence of alkanes, volatile phenols and alkyl sulfide in NS wines, while butyrolactone and beta-damascenone were found mainly in EW wines. Row orientation contributed to wine composition and could be used as a management tool for obtaining individual wine styles.
\end{abstract}

Keywords: Vitis vinifera; double pruning management; phenolic compounds; aroma; quality.

Practical Application: The NS row orientation of vineyards is preferable to promote the sunlight exposure of bunches and therefore increase grapevine vigor and the phenolic maturity of the grapes. Knowledge about the impact of row orientation effects on winter wines may help viticulturists to determine the best orientation of their vineyards regarding topography limitations and desired wine styles.

\section{Introduction}

The concept of winter wines is relatively new in Brazil. The first vineyard managed with the double pruning technique was introduced in the coffee region of Três Corações in 2001 (Amorim et al., 2005). Under this management, the grapevines are first spur pruned at the end of winter (August or September) to develop the vegetative cycle with the removal of all clusters. The reproductive cycle then commences after the second spur pruning, realized in January (or February), to allow for grape harvesting during the dry season of winter (July or August), which improves wine grape quality (Mota et al., 2011; Favero et al., 2011; Regina et al., 2011; Pedro et al., 2017).

Vine growth, yield, and grape and wine quality attributes are affected by solar radiation and temperature regimes throughout the growing season (Bergqvist et al., 2001; Bertamini \& Nedunchezhian, 2004; Jogaiah et al., 2012; Chaves et al., 2016). In general, most of the vineyards around the world are north-south (NS) oriented. NS rows, by receiving morning sun on one side and afternoon sun on the other, are better positioned to maximize light interception compared to east-west (EW) rows (Hunter et al., 2016; Campos et al., 2017). On the other hand, EW-oriented rows can capture the largest portion of total radiation in the cluster zone from soil-reflected radiation, and the leaves of EW-oriented vines can also display higher $\mathrm{CO}_{2}$ assimilation, stomatal conductance and transpiration than those with a NW-SE orientation, as demonstrated by Grifoni et al. (2008) and Hunter et al. (2016). However, the reduced light interception in an EW row orientation may also have a negative impact on growth and yield compared to an NS direction (Chorti et al.,
2018; Souza et al., 2019). Hunter \& Volschenk (2018) observed that some wine sensory descriptors had lower scores for the EW row orientation in comparison with NS wines.

Although the choice of row orientation is mainly based on the best sunlight interception by the vine canopies, in some vineyard sites the topography and erosion potential should also be taken into account. To gain further knowledge on the double pruning management technique, this preliminary study aims to investigate the effects of row orientation on Syrah winter wine composition.

\section{Materials and methods}

The experiment was carried out in 2016 in a non-irrigated

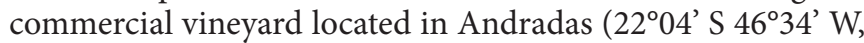
altitude of $920 \mathrm{~m}$ ), south of Minas Gerais State, Brazil. Two adjacent vineyard blocks were north-south (NS) and east-west (EW) oriented and planted in 2007 using 'Syrah,' clone 174 ENTAV-INRA, grafted onto 1103 Paulsen. Each treatment consisted of 200 vines spaced $2.5 \times 1.0 \mathrm{~m}$ apart, trained on a vertical shoot position and spur pruned with two spurs node (approximately 22 buds per vine) on a bilateral Royat Cordon. Double pruning management was applied to allow for grape harvesting during the winter, according to Favero et al. (2011). The first pruning to induce the vegetative cycle was performed in September 2015 in lignified shoots, and all bunches were removed at the bunch closure stage. In March 2016, the yield pruning was conducted in lignified shoots to promote the productive cycle during the autumn-winter season. 
Grapes were harvested with a mean soluble solids content of $21.5^{\circ}$ Brix, pH 3.50 and titratable acidity $5.50 \mathrm{~g} \mathrm{~L}^{-1}$ tartaric acid. Harvested bunches from the two experimental sites were delivered at the winery and stored at $4{ }^{\circ} \mathrm{C}$ for $24 \mathrm{~h}$. For each treatment, two replications of $10 \mathrm{~kg}$ of grape clusters were destemmed, crushed and placed in two 13.25 L Pyrex ${ }^{\circledR}$ glass carboys. The musts were inoculated with rehydrated wine yeast Saccharomyces cerevisiae $\times$ S. kudriavzevii (Maurivin ${ }^{\circledR}$, AWRI 796, $\mathrm{AB}$ Biotek), and $80 \mathrm{mg} \mathrm{SO}_{2} \mathrm{~kg}^{-1}$ was added.

Wine density was determined daily during alcoholic fermentation at $21^{\circ} \mathrm{C}$. When the density reached approximately $990 \mathrm{~g} \mathrm{~L}^{-1}$, the wines were transferred to $5 \mathrm{~L}$ glass carboys for malolactic fermentation that was carried out at $21^{\circ} \mathrm{C}$, without lactic bacteria inoculation, until malic acid was not detected by the paper chromatography method (Amerine \& Ough, 1980). The wines were racked to remove lees, treated with potassium metabisulfite $\left(35 \mathrm{mg} \mathrm{SO}_{2} \mathrm{~L}^{-1}\right)$ and kept at $3{ }^{\circ} \mathrm{C}$ for 15 days to allow tartaric stabilization.

\subsection{Wine composition}

Physicochemical analyses consisted of alcohol, titratable acidity ( $\mathrm{g} \mathrm{L}^{-1}$ tartaric acid), volatile acidity ( $\mathrm{g} \mathrm{L}^{-1}$ acetic acid), $\mathrm{pH}$, residual sugars $\left(\mathrm{g} \mathrm{L}^{-1}\right)$, dry extract $\left(\mathrm{g} \mathrm{L}^{-1}\right)$ and ashes $\left(\mathrm{g} \mathrm{L}^{-1}\right)$ (Amerine \& Ough, 1980). Furthermore, color intensity (CI) $\left(\mathrm{A}_{420}+\mathrm{A}_{520}+\mathrm{A}_{620}\right)$, color hue $\left(\mathrm{A}_{420} / \mathrm{A}_{520}\right)$, total phenolic index (TPI $280 \mathrm{~nm}$ ) and polymerized pigments $\left(\mathrm{A}_{420}\right.$ and $\mathrm{A}_{520}$ with water and $\left.\mathrm{SO}_{2}\right)$ were evaluated by spectrophotometry, and total flavanoid content was evaluated by Bate-Smith reaction (Ribéreau-Gayon et al., 2006). Finally, anthocyanins and phenolics were measured by the $\mathrm{pH}$ differential method and Folin-Ciocalteau method, respectively (Amerine \& Ough, 1980; Giusti \& Wrolstad, 2000). Analyses were performed in triplicate of each glass carboy at bottling.

\subsection{Volatile extraction and analysis}

For the isolation and concentration of volatiles, the headspace solid-phase microextraction technique (HS-SPME) was used according with Gürbüz et al. (2006) with some modifications. All extractions were carried out using a DVB/CAR/PDMS fiber with a film thickness of 50/30 $\mu$ (Supelco, Bellefonte, PA, USA).

An aliquot of $10 \mathrm{~g}$ of wine was placed in $20 \mathrm{~mL}$ vials closed with a Teflon cap and stored at $-20^{\circ} \mathrm{C}$. All samples were prepared in triplicate. Vials were unfrozen at room temperature and then heated to $30^{\circ} \mathrm{C}$ under agitation with a magnetic stir bar for $10 \mathrm{~min}$ for headspace equilibrium. The adsorption time was $45 \mathrm{~min}$ at the same temperature. The SPME fiber was then injected directly into a gas chromatograph mass spectrometer (Agilent Technologies Inc., Santa Clara, USA) operating with ChemStation software. The SPME fiber was held for $10 \mathrm{~min}$ at $250^{\circ} \mathrm{C}$ for desorption of volatile compounds, which were separated using a capillary column HP-5MS $(30 \mathrm{~m} \times 0.25 \mathrm{~mm} \times 0.25 \mu \mathrm{m})$ with helium as the carrier gas at a constant flow of $1 \mathrm{~mL} \mathrm{~min}^{-1}$. The initial oven temperature was set to $40^{\circ} \mathrm{C}$, held for $5 \mathrm{~min}$, then increased to $160{ }^{\circ} \mathrm{C}$ at $3{ }^{\circ} \mathrm{C} \mathrm{min}^{-1}$ and to $250{ }^{\circ} \mathrm{C}$ at $10^{\circ} \mathrm{C} \mathrm{min}^{-1}$ and held for $10 \mathrm{~min}$ before returning to $40^{\circ} \mathrm{C}$, in a total cycle of $64 \mathrm{~min}$ with a transfer line temperature at $250^{\circ} \mathrm{C}$ and the MS detector in SCAN mode $30-500 \mathrm{~m} / \mathrm{z}$.
Volatile compounds were tentatively identified by comparison with the National Institute of Standards and Technology (NIST) library (NIST 11, version 2.0, Gaithersburg, USA) considering a $70 \%$ similarity to the cut-off, further confirming the results with the retention indexes calculated according to the Kovats Index and compared to reported data on the Nist Webbook (National Institute of Standards and Technology, 2020), ChemSpider (2020) or PubChem (National Center for Biotechnology Information, 2020) websites. Relative odors were found on the Good Scents site (The Good Scents Company Information System, 2020). However, only aromatic compounds with a difference in Kovats retention indices lower than 50 units up or down were accepted.

\subsection{Statistical analysis}

All data sets were subjected to analyses of variance (ANOVAs). Tukey's HSD tests were carried out to determine differences between treatment means, using the SAEG software (ver. 9.1, UFV, Viçosa, Brazil). Moreover, a principal component analysis (PCA) was performed on the chemical composition of the wines to investigate the differences between NS and EW row orientations using the MetaboAnalyst program (MetaboAnalyst, 2020).

\section{Results and discussion}

Table 1 reports the results of chemical analysis carried out on the wines at bottling from NS- and EW-oriented vines.

Considering the means of each parameter for both treatments, data on winter wines' composition resemble that of Syrah wines from traditional regions such as Italy (Condurso et al., 2016), South Africa (Hunter \& Volschenk, 2018), California (Pinnell \& Kurtural, 2012; Brillante et al., 2018), Spain (Gutiérrez et al., 2005; Gil et al., 2013) and Australia (Antalick et al., 2015). This confirms the great potential of the double pruning technique for Brazilian viticulture.

Table 1. Physicochemical parameters of Syrah winter wine from north/south (NS) and east/west (EW) oriented vines.

\begin{tabular}{lrrc}
\hline \multicolumn{1}{c}{ Parameter } & \multicolumn{1}{c}{$\mathrm{NS}$} & $\mathrm{EW}$ & Tukey 5\%* \\
\hline Alcohol $(\% \mathrm{vol})$ & $12.86 \mathrm{~b}$ & $13.48 \mathrm{a}$ & 0.191 \\
Residual sugar $\left(\mathrm{g} \mathrm{L}^{-1}\right)$ & $2.60 \mathrm{~b}$ & $2.94 \mathrm{a}$ & 0.312 \\
Dry extract $\left(\mathrm{g} \mathrm{L}^{-1}\right)$ & $27.65 \mathrm{~b}$ & $28.16 \mathrm{a}$ & 0.432 \\
Ashes $\left(\mathrm{g} \mathrm{L}^{-1}\right)$ & $3.42 \mathrm{a}$ & $3.23 \mathrm{~b}$ & 0.119 \\
$\mathrm{pH}$ & $4.03 \mathrm{a}$ & $3.98 \mathrm{~b}$ & 0.020 \\
Total acidity $\left(\mathrm{g} \mathrm{L}^{-1}\right)$ & $5.90 \mathrm{~b}$ & $6.09 \mathrm{a}$ & 0.164 \\
Volatile acidity $\left(\mathrm{g} \mathrm{L}^{-1}\right)$ & $0.55 \mathrm{a}$ & $0.51 \mathrm{~b}$ & 0.012 \\
Total phenolic index $(\mathrm{TPI})$ & $52.30 \mathrm{a}$ & $49.47 \mathrm{~b}$ & 2.184 \\
Total phenolics $\left(\mathrm{mg} \mathrm{L}^{-1}\right)$ & $1,664.48$ & $1,609.01$ & $0.096 \mathrm{~ns}$ \\
total flavanols $\left(\mathrm{mg} \mathrm{L}^{-1}\right)$ & $1,713.93$ & $1,762.25$ & $0.091 \mathrm{~ns}$ \\
Total anthocyanins $\left(\mathrm{mg} \mathrm{L}^{-1}\right)$ & $458.31 \mathrm{a}$ & $440.60 \mathrm{~b}$ & 17.65 \\
Color intensity $\left(\mathrm{A}_{420}+\mathrm{A}_{520}+\mathrm{A}_{620}\right)$ & $13.78 \mathrm{a}$ & $12.37 \mathrm{~b}$ & 0.256 \\
Color hue $\left(\mathrm{A}_{420} / \mathrm{A}_{520}\right)$ & $0.66 \mathrm{~b}$ & $0.68 \mathrm{a}$ & 0.010 \\
Polymerized pigments $(\%)$ & 37.76 & 37.42 & $1.031 \mathrm{~ns}$ \\
\hline Ave & &
\end{tabular}

Average values of three replicates from each glass carboy. ${ }^{\star}$ Significant difference; $n s=$ not statistically significant; same letter in row do not differ significantly between treatments as determined by Tukey's test $(\mathrm{p}<0.05)$. 
Furthermore, the PCA performed on the wine chemical parameters indicated a clear separation between treatments, with titratable acidity, residual sugars, alcohol and color hue with higher intensity on EW wine samples, whereas NS wines demonstrated higher content of color intensity, anthocyanins, total phenolics, total phenolic index, ashes and pH (Figure 1).

The influence of row orientation on alcoholic strength is not clear. Chorti et al. (2018) and Hunter \& Volschenk (2018) did not find a significant difference between the alcohol content in NS and EW row orientations, although Jogaiah et al. (2012) and Souza et al. (2019) observed a slight increase in the soluble solids content in berries from an EW row orientation. Jogaiah et al. (2012) also found a higher potassium content in the must from an NS row, which could explain higher $\mathrm{pH}$ and ashes content in wines from NS-oriented vines.

In addition, Chorti et al. (2018) reported a lower anthocyanin content in wines from EW-oriented rows and higher color and phenolic content values from NS-oriented rows. However, as also observed by Jogaiah et al. (2012), the flavonol concentration did not exhibit differences between treatments.

In EW-oriented rows, the sun passes along the edges of the vine for most of the season, and bunches are less exposed to direct solar radiation. In contrast, in an NS orientation, bunches are exposed to sunlight in the morning on the east side of the canopy and in the afternoon on the west side, thereby ensuring direct sun exposure of the bunches at least in one period during the day. With this orientation, however, the east and west sides of the canopy do not receive the same quantity of radiation, and berries at the west side are exposed to higher temperatures (Hunter \& Volschenk, 2018).

The wine aromatic profile of winter-harvested vines was also influenced by row orientation. The PCA plots demonstrate a clear separation between treatments (Figure 2) of Syrah vineyards at winter harvest, with NS samples located on the positive side of the PC1 and EW samples situated on the negative site.

Among the volatile compounds tentatively identified, esters represent the main class, followed by benzenes and alcohols (Table 2).

Wines were characterized by a greater amount of ester compounds. As mentioned by Ilc et al. (2016), esters are mainly secondary metabolites produced during fermentation from alcohol and acyl-CoA by yeast alcohol acyltransferase enzymes, and they contribute to fruity notes. Aliphatic acids, such as hexanoic acid, n-decanoic acid and octanoic acid, are also formed during fermentation as well as volatile phenols, stored in grapes as glycosides and hydrolyzed during winemaking (Dunlevy et al., 2009; González-Barreiro et al., 2015; Ilc et al., 2016).

The aromatic compounds that distinguished wines from an NS row orientation the most were hexadecane, ortho-cresol and guaiacol, ethyl salicylate and naphthalene, ethyl decanoate and hexanoic acid, methyl ester, while the EW row orientation pointed out with p-xylene, butyrolactone, propyl decanoate, nonanoic acid, ethyl ester and 2-ethylhexyl salicylate (Figure 3).

NS wines pointed out with the presence of alkanes, volatile phenols and alkyl sulfide, while butyrolactone and beta-damascenone

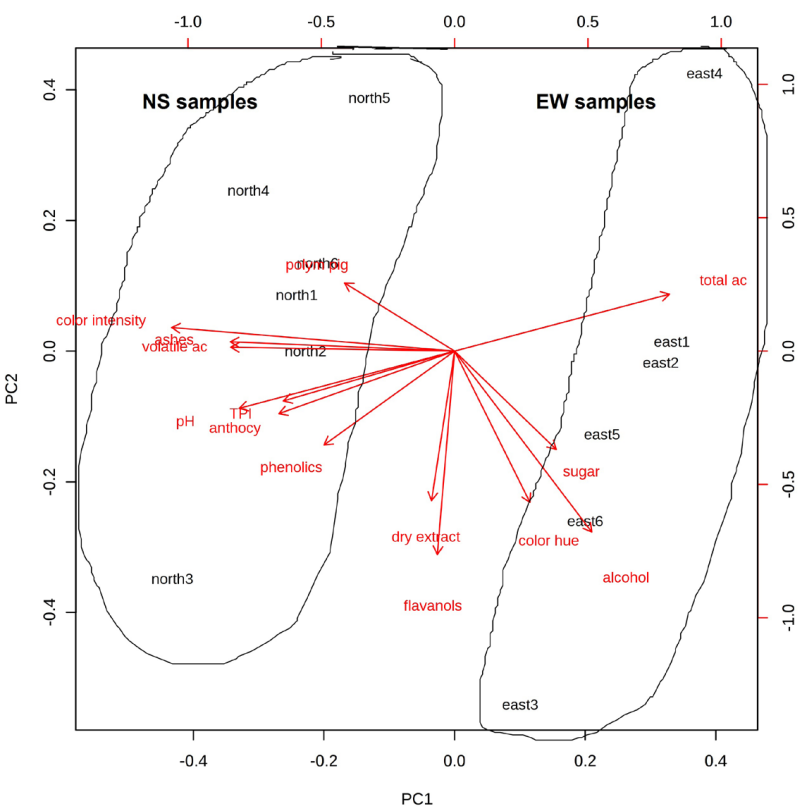

Figure 1. Principal component analysis (biplot graph) of chemical compounds of Syrah winter wines from north/south (NS) and east/west (EW) oriented vines. Principal component 1 (PC1) and PC2 account for $51.5 \%$ and $20.2 \%$ of the total variation in the dataset, respectively.

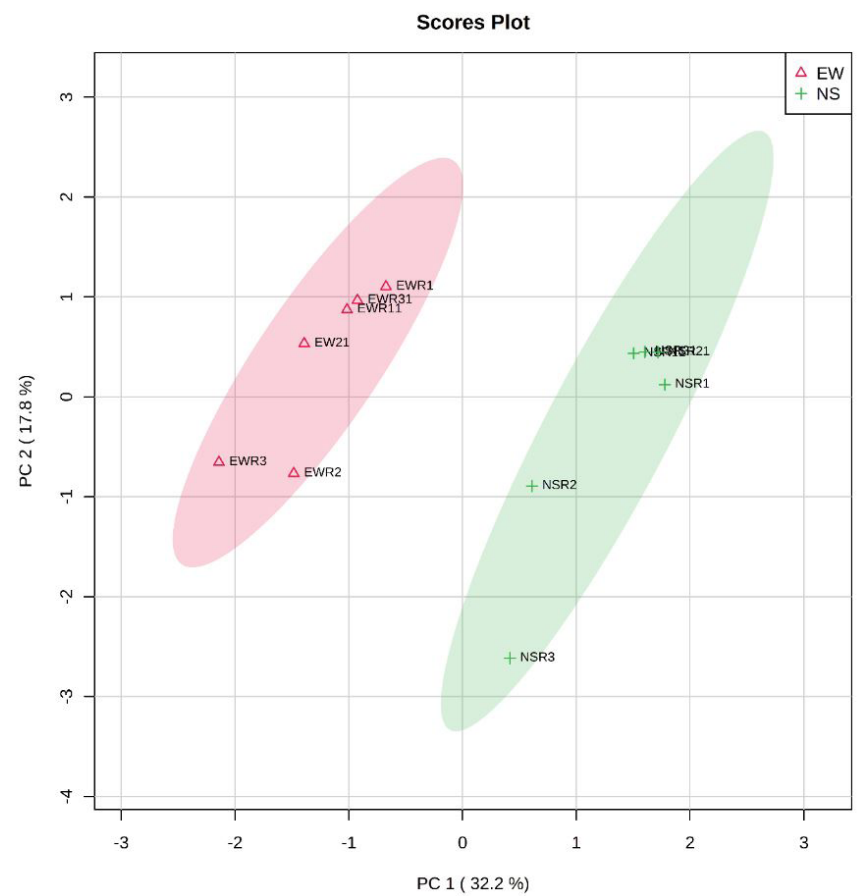

Figure 2. PCA plots for winter wine volatile compounds of Syrah vineyards under north/south (NS) and east/west (EW) orientation. Principal component 1 (PC1) and PC2 account for $32.2 \%$ and $17.8 \%$ of the total variation in the dataset, respectively.

were found mainly in EW wines. Despite the differences, both treatments displayed aromatic compounds with sweet and fruity flavors, with a possible phenolic, spicy and resinous note at the NS orientation and buttery and green nuances at the EW row. Future sensory evaluation, however, is necessary to evaluate consumers' perceptions of these differences. 
Mota et al.

Table 2. Aromatic volatile compounds tentatively identified in winter wines of the Syrah cultivar under north/south (NS) and east/west (EW) orientation.

\begin{tabular}{|c|c|c|c|c|}
\hline compound & code & $\mathrm{CAS}^{\mathrm{c}}$ & Kovats $^{\mathrm{a}}$ & Odor $^{\mathrm{b}}$ \\
\hline \multicolumn{5}{|l|}{ Acids } \\
\hline Hexanoic acid & AJ & $142-62-1$ & 994 & Rancid, sour, sharp, pungent, cheesy, fatty \\
\hline n-Decanoic acid & AN & $334-48-5$ & 1375 & Unpleasant rancid, sour, fatty, citrus, soapy \\
\hline Octanoic acid & $\mathrm{AH}$ & $124-07-2$ & 1191 & Fruity-acid \\
\hline \multicolumn{5}{|l|}{ Alkanes } \\
\hline Hexadecane & $\mathrm{AP}$ & $544-76-3$ & 1600 & Mild wax \\
\hline 1-Hexanol & $\mathrm{U}$ & $111-27-3$ & 875 & Herbaceous, woody, sweet, green fruit, banana, flower, grass \\
\hline 1-Octanol & $\mathrm{W}$ & $111-87-5$ & 1068 & Fresh, orange-rose, sweet, bitter almond, burnt matches, fat, floral \\
\hline Cis-3-hexen-1-ol & AT & $928-96-1$ & 858 & Grassy-green, herbaceous, leafy \\
\hline Phenylethyl alcohol & A & $60-12-8$ & 1113 & Floral, rose, dried rose, flower, rose water \\
\hline \multicolumn{5}{|l|}{ Aldehydes } \\
\hline \multicolumn{5}{|l|}{ Benzenes } \\
\hline Benzaldehyde & $\mathrm{H}$ & $100-52-7$ & 964 & Bitter almond \\
\hline Benzyl alcohol & G & $100-51-6$ & $1039 / 1037$ & Fruity, pungent \\
\hline Ethyl salicylate & AA & $118-61-6$ & 1271 & Sweet, wintergreen, mint, floral, spicy, balsam \\
\hline Naphthalene & $\mathrm{C}$ & $91-20-3$ & 1179 & Pungent, resinous \\
\hline p-Xylene & $\mathrm{P}$ & $106-42-3$ & 871 & Sweet \\
\hline Styrene & $\mathrm{F}$ & $100-42-5$ & 892 & Sweet, balsam, floral, plastic \\
\hline \multicolumn{5}{|l|}{ Ketones } \\
\hline (E)-Beta-damascenone & $\mathrm{BB}$ & $23726-93-4$ & 1385 & Apple, rose, honey, tobacco, sweet \\
\hline \multicolumn{5}{|l|}{ Alkyl sulfide } \\
\hline 1-propanol, 3-(methylthio)- & $\mathrm{AO}$ & $505-10-2$ & 983 & Sulfurous, onion, sweet, soup, vegetable \\
\hline Ethyl butyrate & $\mathrm{J}$ & $105-54-4$ & 800 & Fruity, juicy, pineapple, cognac \\
\hline Ethyl crotonate & $\mathrm{BA}$ & $6776-19-8$ & 854 & $\begin{array}{l}\text { Found in alcoholic beverages. Component of strawberry aroma, guava } \\
\text { fruit, pineapple, yellow passion fruit }\end{array}$ \\
\hline Ethyl decanoate & $\mathrm{R}$ & $110-38-3$ & $1400 / 1397$ & Sweet, waxy, fruity, apple, grape, oily, brandy \\
\hline Ethyl 9-decenoate & $\mathrm{BF}$ & $67233-91-4$ & 1390 & Fruity, fatty \\
\hline Ethyl heptanoate & M & $106-30-9$ & 1101 & Fruity, pineapple, cognac, rum, wine \\
\hline Ethyl laurate & $\mathrm{O}$ & $106-33-2$ & 1596 & Sweet, waxy, floral, soapy, clean \\
\hline Ethyl palmitate & AS & $628-97-7$ & 1917 & Mild, waxy, fruity, creamy, milky, balsam \\
\hline Hexanoic acid, ethyl ester & $\mathrm{AE}$ & $123-66-0$ & 1003 & Fruity - pineapple, banana \\
\hline Hexanoic acid, methyl ester & Q & $106-70-7$ & 933 & Ether-like \\
\hline Hexanoic acid, 2-methylbutyl ester & AY & $2601-13-0$ & 1257 & Ethereal \\
\hline Isoamyl decanoate & $\mathrm{AX}$ & $2306-91-4$ & 1649 & Waxy, banana, fruity, sweet, cognac, green \\
\hline Isoamyl octanoate & AV & $2035-99-6$ & 1449 & Sweet, oily, fruity, green, soapy, pineapple, coconut \\
\hline Isobutyl hexanoate & $\mathrm{K}$ & $105-79-3$ & 1156 & Sweet, fruity, pineapple, green, peach, tropical \\
\hline Isopentyl hexanoate & AW & 2198-61-0 & 1254 & Fruity, banana, apple, pineapple, green \\
\hline Methyl decanoate & S & $110-42-9$ & 1327 & Oily, wine, fruity, floral \\
\hline Methyl laurate & $\mathrm{V}$ & $111-82-0$ & 1526 & Waxy, soapy, creamy, coconut, mushroom \\
\hline Nonanoic acid, ethyl ester & $\mathrm{AD}$ & $123-29-5$ & 1298 & Fruity, rose, waxy, rum, wine, natural, tropical \\
\hline
\end{tabular}

${ }^{a}$ Linear retention indices calculated on capillary HP-5MS column according to Kovats equation. Data were considered within the mean \pm 50 units respect to those reported on Nist,

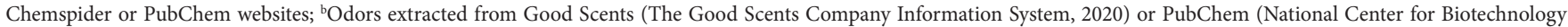
Information, 2020) websites. ${ }^{c} \mathrm{CAS}$ number: unique numeric identifier of a chemical substance in the Chemical Abstracts Service (CAS), a division of the American Chemical Society. 
Table 2. Continued...

\begin{tabular}{|c|c|c|c|c|}
\hline compound & code & $\mathrm{CAS}^{\mathrm{c}}$ & Kovats $^{\mathrm{a}}$ & Odor $^{\mathrm{b}}$ \\
\hline Octanoic acid, ethyl ester & $\mathrm{N}$ & $106-32-1$ & $1202 / 1199$ & Fruity, wine, waxy, sweet, apricot, banana, brandy, pear \\
\hline Octanoic acid, methyl ester & $\mathrm{T}$ & 111-11-5 & 1128 & Winy, fruity - orange, oily \\
\hline Pentadecanoic acid, ethyl ester & $\mathrm{BE}$ & $41114-00-5$ & 1872 & Honey, sweet \\
\hline Phenethyl acetate & I & $103-45-7$ & 1259 & Floral, rose, sweet, honey, fruity, tropical \\
\hline Propyl decanoate & $\mathrm{BC}$ & $30673-60-0$ & 1492 & Waxy, fruity, fatty, green, vegetable, woody, oily \\
\hline Propyl octanoate & AQ & $624-13-5$ & 1294 & Coconut, caco, gin \\
\hline \multicolumn{5}{|l|}{ Volatile phenols } \\
\hline Ortho-cresol & $\mathrm{D}$ & $95-48-7$ & 1061 & Musty, phenolic, plastic, medicinal, herbal, leathery \\
\hline Phenol, 2-methoxy- & B & $90-05-1$ & 1090 & Phenolic, smoke, spice, vanilla woody \\
\hline \multicolumn{5}{|l|}{ Lactones } \\
\hline Butyrolactone & $\mathrm{E}$ & $96-48-0$ & 918 & Sweet, aromatic, buttery, creamy, oily, fatty, caramel \\
\hline Theaspirane & $\mathrm{BD}$ & $36431-72-8$ & 1296 & Tea, herbal, green, wet, tobacco, leaf, metallic, woody, spicy \\
\hline
\end{tabular}

${ }^{a}$ Linear retention indices calculated on capillary HP-5MS column according to Kovats equation. Data were considered within the mean \pm 50 units respect to those reported on Nist, Chemspider or PubChem websites; 'Odors extracted from Good Scents (The Good Scents Company Information System, 2020) or PubChem (National Center for Biotechnology Information, 2020) websites. 'CAS number: unique numeric identifier of a chemical substance in the Chemical Abstracts Service (CAS), a division of the American Chemical Society.

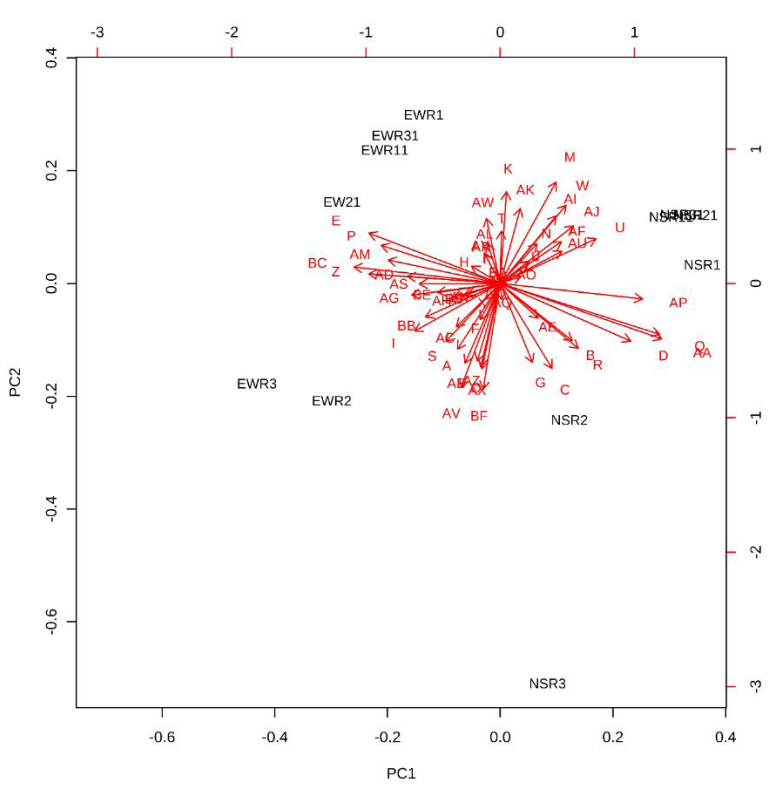

Figure 3. Principal component analysis (biplot graph) of volatile compounds for Syrah winter wines from vines under north/south (NS) and east/west (EW) orientation. Principal component 1 (PC1) and PC2 account for $32.2 \%$ and $17.8 \%$ of the total variation in the dataset, respectively.

\section{Conclusion}

Row orientation impacts grape and wine quality from winter harvests: NS-oriented vines resulted in wines with higher content of color intensity, anthocyanins, total phenolics, ashes and $\mathrm{pH}$. Furthermore, the identification of volatile compounds also revealed differences between treatments. However, the composition of both treatments did not depreciate the quality of the wine, indicating that row orientation could be used as a management tool for obtaining different wine styles.

\section{References}

Amerine, M. A., \& Ough, C. S. (1980). Methods for analysis of musts and wines (341 p.). New York: John Wiley \& Sons.

Amorim, D. A., Favero, A. C., \& Regina, M. A. (2005). Produção extemporânea da videira, cv. Syrah, nas condições do sul de Minas Gerais. Revista Brasileira de Fruticultura, 27(2), 327-331. http:// dx.doi.org/10.1590/S0100-29452005000200036.

Antalick, G., Šuklje, K., Blackman, J. W., Meeks, C., Deloire, A., \& Schmidtke, L. M. (2015). Influence of grape composition on red wine ester profile: comparison between Cabernet Sauvignon and Shiraz cultivars from Australian Warm Climate. Journal of Agricultural and Food Chemistry, 63(18), 4664-4672. http://dx.doi.org/10.1021/acs. jafc.5b00966. PMid:25905977.

Bergqvist, J., Dokoozlian, N., \& Ebisuda, N. (2001). Sunlight exposure and temperature effects on berry growth and composition of Cabernet Sauvignon and Grenache in the Central San Joaquin Valley of California. American Journal of Enology and Viticulture, 52(1), 1-7.

Bertamini, M., \& Nedunchezhian, N. (2004). Photosynthetic responses for Vitis vinifera plants grown at different photon flux densities under field conditions. Biologia Plantarum, 48(1), 149-152. http:// dx.doi.org/10.1023/B:BIOP.0000024294.75496.a6.

Brillante, L., Martínez-Lüscher, J., \& Kurtural, S. K. (2018). Applied water and mechanical canopy management affect berry and wine phenolic and aroma composition of grapevine (Vitis vinifera L., cv. Syrah) in Central California. Scientia Horticulturae, 227, 261-271. http://dx.doi.org/10.1016/j.scienta.2017.09.048.

Campos, I., Neale, C. M. U., \& Calera, A. (2017). Is row orientation a determinant factor for radiation interception in row vineyards? Australian Journal of Grape and Wine Research, 23(1), 77-86. http:// dx.doi.org/10.1111/ajgw.12246.

Chaves, M. M., Costa, J. M., Zarrouk, O., Pinheiro, C., Lopes, C. M., \& Pereira, J. S. (2016). Controlling stomatal aperture in semi-arid regions: the dilemma of saving water or being cool? Plant Science, 251, 54-64. http://dx.doi.org/10.1016/j.plantsci.2016.06.015. PMid:27593463.

ChemSpider. (2020). Retrieved from www.chemspider.com 
Chorti, E., Theocharis, S., Boulokostas, K., Kallithraka, S., Kotseridis, Y., \& Koundouras, S. (2018). Row orientation and defoliation effects on grape composition of Vitis vinifera L. Agiorgitiko in Nemea (Greece). E3S Web of Conferences, 50, 01039. http://dx.doi. org/10.1051/e3sconf/20185001039.

Condurso, C., Cincotta, F., Tripodi, G., Sparacio, A., Giglio, D. M. L., Sparla, S., \& Verzera, A. (2016). Effects of cluster thinning on wine quality of Syrah cultivar (Vitis vinifera L.). European Food Research and Technology, 242(10), 1719-1726. http://dx.doi.org/10.1007/ s00217-016-2671-7.

Dunlevy, J. D., Kalua, C. M., Keyzers, R. A., \& Boss, P. K. (2009). The production of flavour \& aroma compounds in grape berries. In $\mathrm{K}$. A. Roubelakis-Angelakis (Ed.), Grapevine molecular physiology \& biotechnology (2nd ed.). Dordrecht: Springer. http://dx.doi. org/10.1007/978-90-481-2305-6_11.

Favero, A. C., Amorim, D. A., Mota, R. V., Soares, A. M., Souza, C. R., \& Regina, M. A. (2011). Double-pruning of 'Syrah' grapevines: a management strategy to harvest wine grapes during the winter in the Brazilian Southeast. Vitis, 50(4), 151-158.

Gil, M., Esteruelas, M., González, E., Kontoudakis, N., Jiménez, J., Fort, F., Canals, J. M., Hermosín-Gutiérrez, I., \& Zamora, F. (2013). Effect of two different treatments for reducing grape yield in Vitis vinifera cv Syrah on wine composition and quality: Berry Thinning versus Cluster Thinning. Journal of Agricultural and Food Chemistry, 61(20), 4968-4978. http://dx.doi.org/10.1021/jf400722z. PMid:23627566.

Giusti, M. M., \& Wrolstad, R. E. (2000). Characterization and measurement of anthocyanins by uv-visible spectroscopy (Current Protocols in Food Analytical Chemistry). New York: John Willey \& Sons.

González-Barreiro, C., Rial-Otero, R., Cancho-Grande, B., \& SimalGándara, J. (2015). Wine aroma compounds in grapes: a critical review. Critical Reviews in Food Science and Nutrition, 55(2), 202-218. http://dx.doi.org/10.1080/10408398.2011.650336. PMid:24915400.

Grifoni, D., Carreras, G., Zipoli, G., Sabatini, F., Dalla Marta, A., \& Orlandini, S. (2008). Row orientation effect on UV-B, UV-A and PAR solar irradiation components in vineyards at Tuscany, Italy. International Journal of Biometeorology, 52(8), 755-763. http://dx.doi. org/10.1007/s00484-008-0168-1. PMid:18594874.

Gürbüz, O., Rouseff, J. M., \& Rouseff, R. L. (2006). Comparison of aroma volatiles in commercial Merlot and Cabernet Sauvignon wines using gas chromatography-olfactometry and gas chromatography-mass spectrometry. Journal of Agricultural and Food Chemistry, 54(11), 3990-3996. http://dx.doi.org/10.1021/jf053278p. PMid:16719525.

Gutiérrez, I. H., Lorenzo, E. S., \& Espinosa, A. V. (2005). Phenolic composition and magnitude of copigmentation in young and shortly aged red wines made from the cultivars, Cabernet Sauvignon, Cencibel, and Syrah. Food Chemistry, 92(2), 269-283. http://dx.doi. org/10.1016/j.foodchem.2004.07.023.
Hunter, J. J., \& Volschenk, C. G. (2018). Chemical composition and sensory properties of non-wooded and wooded Shiraz (Vitis vinifera L.) wine as affected by vineyard row orientation and grape ripeness level. Journal of the Science of Food and Agriculture, 98(7), 2689-2704. http://dx.doi.org/10.1002/jsfa.8763. PMid:29077197.

Hunter, J. J., Volschenk, C. G., \& Zorer, R. (2016). Vineyard row orientation of Vitis vinifera L. cv. Shiraz/101-14 Mgt: climatic profiles and vine physiological status. Agricultural and Forest Meteorology, 228-229, 104-119. http://dx.doi.org/10.1016/j.agrformet.2016.06.013.

Ilc, T., Werck-Reichhart, D., \& Navrot, N. (2016). Meta-analysis of the core aroma components of grape and wine aroma. Frontiers of Plant Science, 7, 1472. http://dx.doi.org/10.3389/fpls.2016.01472. PMid:27746799.

Jogaiah, S., Striegler, K. R., Bergmeier, E., \& Harris, J. (2012). Influence of cluster exposure to sun on fruit composition of 'Norton' grapes (Vitis estivalis Michx) in Missouri. International Journal of Fruit Science, 12(4), 410-426. http://dx.doi.org/10.1080/15538362.2012.679180.

MetaboAnalyst. ((2020). Retrieved from www.metaboanalyst.ca

Mota, R. V., Silva, C. P. C., Favero, A. C., Purgatto, E., Shiga, T. M., \& Regina, M. A. (2011). Composição físico-química de uvas para vinho fino em ciclos de verão e inverno. Revista Brasileira de Fruticultura, 32(4), 1127-1137. http://dx.doi.org/10.1590/S010029452011005000001.

National Center for Biotechnology Information - NCBI. (2020). Retrieved from www.pubchem.ncbi.nlm.nih.gov

National Institute of Standards and Technology - NIST. (2020). Chemistry WebBook. Gaithersburg. Retrieved from https://webbook.nist.gov

Pedro, M. J. Jr., Hernandes, J. L., Bardin-Camparotto, L., \& Blain, G. C. (2017). Plant parameters and must composition of 'Syrah' grapevine cultivated under sequential summer and winter growing seasons. Bragantia, 76(2), 345-351. http://dx.doi.org/10.1590/1678-4499.146.

Pinnell, S. \& Kurtural, S. K. (2012). Improvement of phenolic composition of Syrah. Practical Winery \& Vineyard Journal, Spring, 1-4.

Regina, M. A., Mota, R. V., Souza, C. R., \& Favero, A. C. (2011). Viticulture for fine wines in Brazilian southeast. Acta Horticulturae, (910), 113-120. http://dx.doi.org/10.17660/ActaHortic.2011.910.8.

Ribéreau-Gayon, P., Glories, Y., Maujean, A., \& Dubourdieu, D. (2006). The chemistry of wine: stabilization and treatments (2nd ed., Handbook of Enology, Vol. 2, pp. 141-203). Chichester: John Wiley \& Sons. http://dx.doi.org/10.1002/0470010398.ch6.

Souza, C. R., Mota, R. V., Silva, C. P. C., Raimundo, R. H. P., Fernandes, F. P., \& Peregrino, I. (2019). Row orientation effects on Syrah grapevine performance during winter growing season. Revista Ceres, 66(3), 184-190. http://dx.doi.org/10.1590/0034-737x201966030004.

The Good Scents Company Information System. (2020). Retrieved from www.thegoodscentscompany.com 